\title{
PEMBERDAYAAN MASYARAKAT MISKIN MELALUI PROGRAM USAHA PENINGKATAN PENDAPATAN KELUARGA SEJAHTERA (UPPKS) DI KOTA PADANG PANJANG
}

\author{
Muntaha Mardhatillah, \\ Email: iilmuntaha@gmail.com
}

\begin{abstract}
ABSTRAK
Penelitian ini bertujuan untuk mengetahui bagaimana proses pelaksanaan program usaha peningkatan pendapatan keluarga sejahtera di Kota Padang Panjang, mengidentifikasi kendala-kendala yang ditemui serta mengetahui upaya yang ditempuh dalam mengatasi kendala dalam pelaksanaan program tersebut. Penelitian ini dilatar belakangi oleh belum semuanya masyarakat dari golongan miskin yang diikutsertakan, usaha dilakukan tidak secara kolektif, kurangnya partisipasi dari kelompok keluarga sejahtera III plus untuk mau bertindak sebagai bapak angkat, jumlah modal yang diberikan pemerintah kurang mencukupi dalam penyelenggaraan kegiatan UPPKS dan modal yang sering di salah gunakan untuk keperluan konsumtif.

Metode yang digunakan dalam penelitian adalah kualitatif dengan menggunakan metode deskriptif, karena penelitian memberikan gambaran tentang keadaan sebagaimana mestinya. Pemilihan informan dilakukan secara purposive sampling. Jenis datanya adalah data primer dan data sekunder yang dikumpulkan melalui observasi, wawancara dan studi dokumentasi. Uji keabsahan dilakukan melalui trianggulasi sumber. Kemudian teknik analisa data yang digunakan dapat dikelompokkan dalam 3 tahap yaitu reduksi data, penyajian dan penarikan kesimpulan.

Temuan penelitian menunjukkan bahwa pelaksanaan program UPPKS telah sesuai dengan prosedur yang ada namun belum sepenuhnya mampu meningkatkan kesejahteraan anggotanya dan belum optimal. Hal ini dapat dilihat dengan masih ditemukannya kendala dalam pelaksanaan, kendala yang dihadapi dalam pelaksanaan program UPPKS di Kota Padang Panjang dapat dikategorikan kedalam dua bentuk yaitu kendala internal dan kendala eksternal. Kendala internal diantaranya : lemahnya pengawasan terhadap program, kurangnya modal yang bersumber dari pemerintah, pembinaan yang belum merata. Dan kendala eksternal diantaranya : pemanfaatan dana bantuan yang belum maksimal, kurangnya kreatifitas dan inovasi beberapa kelompok dalam mencari dan memanfaatkan sumber dana, keterlambatan pengembalian pinjaman. Untuk mengatasi kendala dalam proses pelaksanaan program UPPKS, dilakukan upaya antara lain mengikut sertakan keluarga sejahtera III bertindak sebagai bapak angkat dalam keompok, melakukan pembinaan, dan kendala yang bersumber dari peserta program dilakukan upaya seperti pembimbingan mengenai tujuan sebenarnya program UPPKS ini, melakukan sistem jemput bola terhadapa anggota yang macet dalam pembayaran.
\end{abstract}

Kata Kunci : Pemberdayaan masyarakat, Kemiskinan, Program UPPKS, Kota Padang Panjang

\section{ABSTRACT}

This study aims to determine how the process of implementing a business program to increase the income of prosperous families in the city of Padang Panjang, identify the 
obstacles encountered and find out the efforts taken in overcoming obstacles in the implementation of the program. This research is motivated by the fact that not all people from the poor are included, efforts are not carried out collectively, lack of participation from prosperous family groups III plus to want to act as foster father, the amount of capital provided by the government is insufficient in the implementation of UPPKS activities and often capital in the wrong use for consumptive purposes.

The method used in this research is qualitative by using descriptive methods, because the study provides a description of the situation as it should. The selection of informants is done by purposive sampling. The type of data is primary data and secondary data collected through observation, interviews and documentation studies. The validity test is done through triangulation of sources. Then the data analysis techniques used can be grouped in 3 stages, namely data reduction, presentation and drawing conclusions.

Research findings indicate that the implementation of the UPPKS program is in accordance with existing procedures but has not been fully able to improve the welfare of its members and is not optimal. This can be seen with the still found obstacles in the implementation, the obstacles encountered in the implementation of the UPPKS program in the city of Padang Panjang can be categorized into two forms, namely internal and external constraints. Internal constraints include: weak oversight of the program, lack of capital sourced from the government, uneven development. And external constraints include: the use of aid that has not been maximized, the lack of creativity and innovation of some groups in finding and utilizing sources of funds, the late repayment of loans. To overcome obstacles in the process of implementing the UPPKS program, efforts were made to include prosperous families III acting as foster fathers in groups, conducting coaching, and constraints originating from program participants made efforts such as mentoring regarding the UPPKS program's true purpose, conducting a ball pick-up system on the member who is stuck in payment.

Keywords: Community Empowerment, Poverty, UPPKS Program, Padang Panjang City 


\section{A. Pendahuluan}

Negara-negara berkembang di dunia masih banyak mengalami problematika kemiskinan Salah satu negara yang masih mempunyai masalah kemiskinan adalah Indonesia. Padang Panjang merupakan salah satu kota terkecil yang ada di Indonesia yang berada di wilayah Propinsi Sumatera Barat. Padang Panjang mempunyai luas 2.300 Ha atau sekitar 0,05 persen dari luas Sumatera Barat. Data yang didapat dari badan pusat statistik kota Padang Panjang menyatakan jumlah penduduk Padang Panjang pada tahun 2012 adalah sekitar 47.619 jiwa dan yang tercatat sebabgai keluarga miskin adalah 6.548 jiwa atau sekitar $14 \%$ dari jumlah penduduk yang ada, dan dari $14 \%$ penduduk miskin yang ada terdapat sekitar 268 jiwa penduduk miskin yang berstatus sebagai janda atau sekitar $0,6 \%$, hal ini tentu perlu mendapatkan perhatian dari pemerintah.

Salah satu bentuk upaya yang dilakukan pemerintah untuk menanggulangi kemiskinan tersebut adalah melalui pendekatan pemberdayaan keluarga yang mengacu pada UU No.10 Tahun 1992 tentang Perkembangan Kependudukan dan Pembangunan Keluarga Sejahtera yang pelaksanaannya diatur dalam Inpres Nomor 3 Tahun 1996 tentang Pembangunan Keluarga Sejahtera dalam Rangka Peningkatan Penanggulangan Kemiskinan.

Di sini BKKBN sebagai penyelenggara pemberdayaan keluarga dari pemerintah membuat sebuah program Pemberdayaan Ekonomi Keluarga dengan membentuk suatu wadah kelompok Usaha Peningkatan Pendapatan Keluarga Sejahtera (UPPKS). Tujuan umum dari kelompok UPPKS adalah untuk memberdayakan ibu-ibu/wanita di bidang ekonomi sebagai upaya peningkatan penanggulangan kemiskinan dalam rangka membangun kemandirian dan ketahanan keluarga serta mewujudkan keluarga kecil, bahagia, dan sejahtera.

Usaha Peningkatan Pendapatan Keluarga Sejahtera (UPPKS) merupakan kegiatan usaha ekonomi produktif keluarga, terutama kaum ibu dalam rangka meningkatkan derajat kesejahteraan keluarga. Usaha Peningkatan Pendapatan Keluarga Sejahtera dikembangkan melalui pendekatan kelompok dengan penyediaan modal kerja dari berbagai sumber dana yang diberikan pada setiap kelompok. Kelompok ini beranggotakan dari berbagai tahapan keluarga sejahtera, mulai dari tahapan keluarga Pra Sejahtera sampai kepada Keluarga Sejahtera III Plus (Profil UPPKS 2009).

Sasaran dari Usaha Peningkatan Pendapatan Kelurga Sejahtera ini adalah para keluaraga Pra Sejahtera yang beminat dalam melakukan usaha ekonomi keluarga ataupun yang sudah mempunyai usaha. Para keluarga Pra Sejahtera (kelurga kurang mampu) bersama-bersama dengan Keluarga Sejahtera III Plus membentuk suatu kelompok yang terdiri dari 10 samapai 20 anggota, dan memilih kepengurusan yang terdiri dari ketua, sekretaris, bendahara. Pentingnya peranan keluarga dari Keluarga Sejahtera III Plus dimaksudkan untuk dapat membimbing para keluarga dari Kelurga Pra Sejahtera.

Di kota Padang Panjang sendiri, penyelenggaraan UPPKS dilaksanakan oleh kantor pemberdayaan perempuan dan keluarga berencana, hal ini sesuai dengan keputusan walikota Padang Panjang Nomor 23 Tahun 2008 Tentang Tugas Pokok, Fungsi dan Uraian Tugas Kantor Pemberdayaan Perempuan dan Keluarga Berencana Kota Padang Panjang menetapkan tugas pokok dan fungsi kantor pemberdayaan perempuan dan keluarga berencana kota Padang Panjang, yaitu salah satunya melakukan, mengendalikan dan mengevaluasi pelaksanaan program keluarga sejahtera dan pemberdayaan keluarga yang mencakup program pemberdayaan ekonomi keluarga. 
Kantor pemberdayaan perempuan dan keluarga berencana kota Padang Panjang sebagai pelaksana dalam program Usaha Peningkatan Pendapatan keluarga Sejahtera (UPPKS) di kota Padang Panjang, juga mengajak para anggota UPPKS untuk mau ikut serta kedalam program keluarga berencana, hal ini juga sejalan dengan tugas pokok dan fungsi kantor pemberdayaan perempuan dan keluarga berencana yaitu salah satunya untuk menyelenggarakan program keluarga berncana dan keluarga sejahtera.

Menurut wawancara dengan Netti Herawati, S.H, M.M , kepala TU kantor pemberdayaan perempuan dan keluarga berencana kota Padang Panjang tanggal 15 Oktober 2012:

"Semenjak tahun 1990 yang pada awalnya bernama Usaha Peningkatan Pendapatan Keluarga Akseptor (UPPKA), UPPKA tersebut hanya bertujuan untuk mengembangkan potensi peserta KB. Namun seiring perkembangannya UPPKA, di ubah menjadi UPPKS dengan cakupan yang lebih luas yaitu tidak hanya terbatas pada keluarga akseptor KB saja. Sekarang kelompok UPPKS di kota Padang Panjang sudah berjumlah sebanyak 32 kelompok UPPKS yang tersebar di 16 kelurahan yang ada di kota Padang Panjang, jumlah modal yang terkumpul pada tahun 2012 ini adalah sebanyak 187 juta yang berasal dari APBD, bantuan pemda, dana dari BKKBN pusat dan dari BKKBN provinsi”.

Tabel 1.1

Daftar kelompok Usaha Peningkatan Pendapatan Keluarga Sejahtera (UPPKS) di Kota Padang panjang :

No Lokasi Nama Kelompok UPPKS

1 Kelurahan Silaing Bawah : Teratai, Flamboyan, Lili Paris

2 Kelurahan Silaing Atas : Mawar Putih

3 Kelurahan Pasar Usang : Melati II, Bunga Lidah Buaya, Anggrek, Mentari

$4 \quad$ Kelurahan Bukit Surungan : Busur I, Busur II

$5 \quad$ Kelurahan Pasar Baru : Sejahtera I, Sejahtera II

6 Kelurahan Balai Balai : Makmur II

7 Kelurahan Tanah Hitam : Sartika, Kartini, Fadhillah

8 Kelurahan Kampung Manggis : Manggis Permai, Restu Ibu

9 Kelurahan Guguk Malintang : Gumala I, Gumala II, Gilang Jaya

10 Kelurahan Koto Panjang : Sabai Nan Aluih, Garuda I, Garuda IV

11 Kelurahan Ngalau : Makmur

12 Kelurahan Ekor Lubuk : Cempaka Putih

13 Kelurahan Tanah Pak Lambik : Dahlia

14 Kelurahan Koto Katik : Merpati Putih

15 Kelurahan Ganting : Flamboyan, Bina Sejahtera

16 Kelurahan Sigando : Amanah I, Amanah II

Sumber : Kantor Pemberdayaan Perempuan Dan Keluarga Berencan Kota Padang Panjang, 2012.

Masalah yang ditemui didalam pelaksanaan UPPKS di kota Padang Panjang adalah belum semuanya masyarakat miskin yang ikut serta kedalam program UPPKS ini, padahal jika dilihat pada tabel 1.1 mengenai rekapitulasi masyarakat miskin kota Padang Panjang masih banyak masyarakat miskin yang membutuhkan program ini. Hal ini salah satunya disebabkan oleh kurangnya sosialisasi yang dilakukan oleh kantor pemberdayaan perempuan dan keluarga berencana dalam mengenalkan program UPPKS ini kepada masyarakat miskin yang ada di kota Padang Panjang. 
Jenis usaha yang dilakukan oleh masing-masing anggota didalam satu kelompok UPPKS juga bermasalah yang mana seharusnya jenis usaha yang dilakukan seragam pada setiap kelompok, hal ini bertujuan untuk menfokuskan perhatian masing-masing anggota kelompok terhadap satu usaha, apabila terjadi kendala-kendala dalam menjalankan usaha, tentu akan lebih mudah diselesaikan dengan bantuan anggota lain dikarenakan memiliki tujuan yang sama untuk memajukan usaha yang dijalankannya sehingga dapat menjalankan usaha tersebut secara kolektif. Namun yang ditemui dilapangan yaitu terdapatnya bermacam-macam usaha yang dilakukan oleh anggota UPPKS dalam satu kelompok UPPKS, selain itu masih kurangnya perhatian dari keluarga KS III (keluarga mampu) untuk ikut serta kedalam keanggotaan UPPKS.

Masalah lain yang ditemui yaitunya persoalan mengenai permodalan, yang mana jumlah modal yang diberikan pemerintah kepada kelompok UPPKS ini sangat terbatas, tercatat terakhir pemerintah mengeluarkan dana sebesar Rp. 100.000.000,00 pada tahun 2008. Modal awal yang diberikan pada satu kelompok UPPKS berkisar antara Rp. 2.500.00,00 - Rp. 5.000.000,00 yang dibagi kepada beberapa anggota, masing-masing kelompok UPPKS biasanya beranggotakan 10 - 20 orang anggota, hal ini mempunyai dampak terhadap produksi yang kurang berkualitas dari segi kemasan, sehingga mengurangi daya jual dari produksi yang di hasilkan oleh kelompok UPPKS itu sendiri, belum lagi modal yang diberikan kepada anggota UPPKS seringkali di salah gunakan untuk keperluan konsumtif, yang berakibat pada kurang berkembangnya usaha yang dilakukan oleh anggota UPPKS tersebut.

Selama ini masyarakat yang ikut serta kedalam keanggotaan UPPKS merasa cukup terbantu dengan adanya program UPPKS ini, seperti contoh dalam hal permodalan, yang mana dengan adanya program UPPKS ini masyarakat miskin bisa mendapatkan bantuan modal untuk melakukan usahanya tanpa membutuhkan jaminan sebagai persyaratan dalam memperoleh pinjamam modal.

Berdasarkan uraian diatas, penulis tertarik untuk melakukan penelitian mengenani

"Pemberdayaan Masyarakat Miskin Melalui Usaha Peningkatan Pendapatan Keluarga Sejahtera di Kota Padang Panjang"

\section{B. Rumusan Masalah}

Berdasarkan identifikasi dan batasan masalah sebagaimana yang telah diuraikan di atas, maka dapat dirumuskan permasalahan yang akan diteliti sebagai berikut:

1. Bagaimana pelaksanaan program Usaha Peningkatan Pendapatan Keluarga Sejahtera (UPPKS) di kota Padang Panjang?

2. Apa saja kendala-kendala yang ditemui dalam pelaksanaan program Usaha Peningkatan Pendapatan Keluarga Sejahtera (UPPKS) di kota Padang Panjang?

3. Bagaimana upaya yang dilakukan untuk mengatasi kendala yang ditemui dalam pelaksanaan program Usaha Peningkatan Pendapatan Keluarga Sejahtera (UPPKS) di kota Padang Panjang?

\section{Tujuan Penelitian}

Tujuan penulis dalam penelitian ini adalah :

1. Untuk mendeskripsikan pelaksanaan dari program Usaha Peningkatan Pendapatan Keluarga Sejahtera (UPPKS) di kota Padang Panjang.

2. Untuk mengidentifikasi kendala-kendala yang dihadapi dalam pelaksanaan program Usaha Peningkatan Pendapatan Keluarga Sejahtera (UPPKS) di kota Padang Panjang. 
3. Untuk mengidentifikasi upaya yang dilakukan dalam mengatasi kendala yang ditemui dalam pelaksanaan program Usaha Peningkatan Pendapatan Keluarga Sejahtera (UPPKS) di kota Padang Panjang.

\section{Metode Penelitian}

Penelitian ini bersifat kualitatif dengan menggunakan metode deskriptif. Sehingga penulisan ini akan mendeskripsikan, mencatat, menjelaskan dan memaparkan permasalahan yang diteliti. Hal ini seiring dengan pendapat Bogdan dan Taylor dalam Moleong (2002: 213) mengatakan bahwa penelitian kualitatif adalah penelitian yang menghasilkan data deskriptif berupa kata-kata tertulis atau lisan dari orang-orang atau perilaku yang diamati.

Penelitian kualitatif dengan metode deskriptif adalah suatu jenis penelitian yang bertujuan untuk membuat deskripsi, atau gambaran secara sistematis, faktual dan akurat mengenai fakta-fakta, sifat-sifat serta hubungan antara fenomena yang diselidiki. Berdasarkan uraian tersebut maka penelitian ini bermaksud melakukan penelusuran, deskripsi dan analisis tentang Pemberdayaan Masyarakat Miskin Melalui Usaha Peningkatan Pendapatan Keluarga Sejahtera di Kota Padang Panjang.

\section{E. Pembahasan}

1. Pemberdayaan Masyarakat Miskin Melalui Pogram Usaha Peningkatan Pendapatan Keluarga Sejahtera (UPPKS)

Program Usaha Peningkatan Pendapatan Keluarga Sejahtera (UPPKS) diberikan kepada masyarakat miskin yang dikhususkan kepada ibu-ibu/wanita berupa bantuan modal usaha dalam rangka pengembangan usaha yang dijalankan dan sebagai modal bagi anggotanya tersebut untuk membangun kemampuan dalam meningkatkan pendapatannya. Seperti yang disampaikan oleh Suharto (2005: 58), pemberdayaan menunjuk kepada kemampuan orang, khususnya kelompok rentan sehingga memiliki kemampuan dalam memenuhi kebutuhan dasarnya, meningkatkan pendapatannya, serta berpartisipasi dalam proses pembangunan. A. M. W Pranarka dalam Ony (1996: 263) mengemukakan konsep sederhana tentang pemberdayaan masyarakat, yaitu: suatu proses yang berjalan terus menerus untuk meningkatkan kemampuan dan kemandirian masyarakat dalam meningkatkan taraf hidupnya.

Dalam program UPPKS yang menjadi sasaran dari program ini yaitunya ibuibu/wanita dari keluarga pra sejahtera dan sejahtera I yang berminat dalam melakukan usaha untuk meningkatkan kesejahteraannya. Pemberdayaan perempuan merupakan suatu upaya pemerintah untuk menjadikan perempuan dapat mandiri dengan keterampilan dan potensi yang dimiliki. Pemberdayaan perempuan dilaksanakan salah satunya untuk mengembangkan kemampuan perempuan agar mampu melaksanakan usaha produktif dan mampu mengembangkan usahanya tersebut. Seperti yang dikemukakan Roesmidi dan Risyanti (2006: 111) yaitu pemberdayaan perempuan merupakan tindakan usaha perbaikan atau peningkatan ekonomi, sosial budaya, politik dan psikologi baiak secara individual maupun secara kolektif.

Dalam pemberdayaan masyarakat miskin melalui program usaha peningkatan pendapatan keluarga sejahtera di Kota Padang panjang, tidak sepenuhnya peserta yang bisa meningkatakan kesejahteraannya melalui program ini, masih ditemukannya sekitar $35 \%$ kelompok yang tidak dapat mengembangkan usahanya untuk meningkatkan pendapatan, hal ini dikarenakan kurangnya kreatifitas dan inovasi dalam mencari dan memnfaatkan dana pinjaman yang ada. Karl dalam Sugiarti (2003: 193) berpendapat pemberdayaan dapat dianalisis melalui lima dimensi, yaitu dimensi kesejahteraan, akses 
sumber daya, kesadaran kritis, partisipasi dan control, namun jika dilihat dalam program usaha peningkatan pendapatan keluarga sejahtera di Kota Padang Panjang belum sepenuhnya kelima dimensi tersebut terpenuhi. Dengan demikian dapat disimpulkan bahwa belum maksimalnya pemberdayaan yang dilakukan melalui program UPPKS ini dan tentu saja tidak berhenti begitu saja karena pemberdayaan merupakan proses yang berkelanjutan sehingga masih perlu dilakukan pemberdayaan lebih lanjut agar perempuan sebagai peserta program UPPKS dapat lebih berdaya dan pada akhirnya dapat berdampak positif pada peningkatan pendapatan keluarga mereka.

2. Pelaksanaan Program Usaha Peningkatan Pendapatan Keluarga Sejahtera (UPPKS) di Kota Padang Panjang

Mekanisme pelaksanaan program UPPKS diatur berdasarkan pedoman pengelolaan dan pengembangan kelompok UPPKS 20011, proses pelaksanaan program UPPKS dimulai dari tahap persiapan sampai kepada pelaksanaan. Tahap persiapan dimulai dari pengelolaan kelompok dan pengelolaan administrasi dan keuangan serta pengelolaan usaha kelompok, setelah kelompok UPPKS melakukan tahap persiapan berlanjut keapada pelaksanaan yang dimulai dari pembentukan kelompok, pembuatan proposal usaha, membangun usaha kelompok, serta mengembangkan kelompok. Sesuai dengan Mustopadidjadja (2003: 37) yang menyatakan berhasil atau gagalnya suatu kebijakan tergatung pada beberapa kondisi yaitu : ketepatan pelaksanaan, konsistensi dan keberlanjutan pelaksanaannya serta perkembangan yang terjadi

Penyaluran dana program UPPKS diserahkan melalui koperasi AKU yang berkisar antara Rp. 2.500.000,- sampai Rp. 5.000.000,- untuk peminjaman pertama dengan bunga $0,6 \%$ perbulan, jangka watu peminjaman ini berkisar antara 1-2 tahun, setelah bantuan didapat tanggung jawab diserahkan kepada masing-masing kelompok untuk mengursinya dengan membuat suatu bentuk koperasi kecil dalam kelompok dan setiap anggota harus mempunyai simpanan pokok dan simpanan wajib untuk masingmasingnya, dana yang telah dilunasi akan terus diputarkan bagi kelompok UPPKS yang lainnya, pinjaman dapat ditingkatkan untuk tahap selanjutnya apabila kelompok dapat melunasi pinjaman tersebut dengan lancar atau tidak macet.

Perkembangan program UPPKS yang ada di kota Padang Panjang dari bulan ke bulan mengalami peningkatan yang tercatat dari 25 kelompok yang ada sudah berkembang menjadi 32 kelompok UPPKS pada saat sekarang, serta berkembangya usaha yang dilakukan oleh kelompok UPPKS tersebut kearah yang lebih baik, bisa meningkatkan penghasilan dari sebelumnya. Hal ini membuktikan bahwa bantuan yang diberikan sangat membantu masyarakat miskin terutama ibu-ibu/wanita selaku anggota kelompok UPPKS peserta program.

Pelaksanaan program usaha peningkatan pendapatan keluarga sejahtera memberikan manfaat yang besar bagi perkembangan usaha yang dilakukan oleh ibuibu/wanita dari golongan keluarga pra sejahtera dan sejahtrea I selaku anggota dari program Usaha Peningkatan Pendapatan Keluarga Sejahtera (UPPKS) yaitu diantaranya : untuk mengembangkan usaha yang dijalankan dalam kelompoknya sehingga menambah pengahsilan dan meningkatkan kesejahteraan diri dan keluarganya, program UPPKS juaga meberikan pengetahuan kepada ibu-ibu/wanita yang terdaftar sebgai anggota UPPKS tentang pentingnya ikut $\mathrm{KB}$ dalam ranngka mensukseskan program $\mathrm{KB}$ Nasional.

3. Kendala pelaksanaan program Usaha Peningkatan Pendapatan Keluarga Sejahtera (UPPKS) di Kota Padangpanjang 
Hansen dalam Setia Budi (2005: 27) mengemukakan jenis kendala berdasarkan asalnya terbagi atas kendala internal dan kendala eksternal, begitu juga dengan kendala yang dihadapi dalam pelaksanaan program UPPKS di Kota Padangpanjang dapat dikategorikan kedalam dua bentuk yaitu :

a. Kendala internal, kendala internal merupakan kendala yang menghambat pelaksanaan program UPPKS yang bersumber dari aparat atau petugas yang terlibat dalam pelaksanaan program UPPKS di Kota Padangpanjang. Kendala tersebut antara lain :

1) Lemahnya pengawasan terhadap program yang dilakukan oleh kantor pemberdayaan perempuan dan keluarga berencana. Beragamnya jenis usaha yang dilakukan pada satu kelompok membuktikan pengawasan yang lemah dari kantor pemberdayaan perempuan dan keluarga berencana Kota Padangpanjang, padahal semestinya jenis usah yang dilakukan pada satu kelompok haruslah seragam, belum lagi permasalahan mengenai tidak adanya sanksi tegas terhadap anggota yang melakukan penunggakan dalam peminjaman bantuan, hal ini tentu menghambat perkembangan bagi program UPPKS kedepannya.

2) Kurangnya modal yang bersumber dari pemerintah. Kurangnya dana bantuan yang dimiliki oleh kantor pemberdayaan perempuan dan keluarga berencana Kota Padangpanjang menjadi suatu permasalahan bagi aparatur pelaksana hal ini terjadi dikarenakan masyarakat yang membutuhkan dan memenuhi syarat untuk ikut program sangat banyak sehingga tidak mencukupi untuk dana yang diberikan.

3) Pembinaan yang belum merata. Permasalahan mengenai tidak meratanya pembinaan terhadap usaha kelompok UPPKS terlihat dari masih adanya beberapa kelompok yang mengeluhkan tidak mendapatkan pembinaan untuk mengembangkan produknya, sehingga dapat meningkatkan pendapatan dalam kelompok UPPKS.

b. Kendala eksternal, kendala eksternal merupakan kendala yang menghambat pelaksanaan program UPPKS yang bersumber dari objek program UPPKS yang dalam hal ini yaitu kelompok UPPKS itu sendiri. Kendala tersebut antara lain :

1) Pemanfaatan dana bantuan yang belum maksimal. Sasaran yang ingin dicapai dalam program UPPKS ini yaitunya peningkatan kapasitas masyarakat miskin selaku peserta program sehingga mereka dapat meningkatkan taraf hidup individu maupun keluarganya. Namun dalam pelaksananya masih ada para anggota yang tidak memanfaatkan dana bantuan ini untuk kebutuhan usahanya, mereka malah memanfaatkan dana tersebut untuk keperluan sehari-hari. Hal ini menyebabkan usaha yang dilakukan oleh anggota kelompok UPPKS tersebut tidak dapat berkembang.

2) Kurangnya kreatifitas dan inovasi beberapa kelompok dalam mencari dan memanfaatkan sumber dana.

Besarnya bantuan awal yang diberikan pada masing-masing kelompok UPPKS dirasa belum mencukupi bagi sebagian kelompok sehingga tidak begitu membantu dalam meningkatkan usaha yang dijalankan, namun bagi sebagian kelompok lainnya hal tersebut tidak menjadi Kendal penghalang untuk mengembangkan usahanya, dibutuhkan suatu kreatifitas dan inovasi dalam pemanfaatan dan pencarian dana bantuan yang ada. 
3) Keterlambatan pengembalian pinjaman.

Keterlambatan dalam pembayaran pinjaman membuat terjadinya kredit macet, sehingga menghambat untuk pengembalian pinjaman tersebut dari anggota ke kelompok, ini disebabkan kurangnya kemampuan dalam mengembangkan usaha yang dilakukan faktor lain yang menyebabkan yaitu pemanfaatan dan yang tidak diperuntukkan bagi perkembangan usaha seperti yang dipaparkan sebelumnya.

4. Upaya Mengatsi Kendala dalam Pelaksanaan Program Usaha Peningkatan Pendapatan Keluarga Sejahtera (UPPKS) di Kota Padangpanjang

Kartasasmita (1995: 4) mengatakan bahwa upaya pemberdayaan masyarakat miskin lebih menekankan pada aspek kemandirian dengan memberikan bantuan dari pemerintah guna meningkatkan potensi yang dimiliki oleh masyarakat itu sendiri. Upaya yang telah dilakukan oleh kantor pemberdayaan perempuan dan keluarga berencana Kota Padangpanjang dalam menanggulangi kendala yang dihadapi selama pelaksanaan program UPPKS di Kota Padangpanjang dapat dilihat dari kendala internal, yaitu kendala yang berasal dari petugas pelaksana, kantor pemberdayaan perempuan dan keluarga berencana Kota Padangpanjang berusaha menghimbau para keluarga dari keluarga sejahtera III untuk dapat ikut serta menyukseskan kelompok UPPKS dengan berperan sebagai bapak angkat dalam kelompok UPPKS tersebut.

Terkait dengan pembinaan Dalam hal pembinaan kantor pemberdayaan perempuan dan keluarga berencana kota Padangpanjang bekerja sama dengan Dinas Perindustrian dan Perdagangan yang diantarnya melakukan kegiatan pameran-pameran terhadap hasilhasil usaha dari kelompok UPPKS.

Berdasarkan hasil wawancara dan penyebaran angket, sudah ada beberapa upaya dari pemerintah. Pertama kali yang sudah dilakukan adalah sosialisasi UPPKS ini pada keluarga sejahtera III selaku babak angkat. Bapak angkat membantu dalam hal permodalah, jaringan usaha, mapun keterampilan lain. Bapak angkat ini juga bertindak sebagai pembina terhadap kelompoknya baik sebagai investasi bagi keluarga sejahtera III plus itu sendiri. Selain itu upaya dalam program UPPKS ini harus selalu ditingkatkan, karena mungkin tidak selamanya Bapak Angkat mampu memberikan pembinaan dalam program UPPKS ini. Menurut hemat peneliti, perlu dibentuk pengelola yang khusus untuk mensurvey ke lapangan agar kegiatan ini dapat berjalan sebagaimana mestinya. Bila perlu tim monevnya ditunjuk dari perguruan tinggi yang fakultasnya disesuaikan dengan bentuk jenis usaha yang diberikan.

\section{F. Kesimpulan Dan Saran}

\section{Kesimpulan}

Berdasarkan hasil penelitian dan pembahasan yang telah diungkapakan, maka dapat diambil kesimpulan sebagai berikut :

1. Program usaha peningkatan pendapatan keluarga sejahtera (UPPKS) diberikan kepada masyarakat miskin yang dikhususkan kepada ibu-ibu/wanita berupa bantuan modal usaha dalam rangka pengembangan usaha yang dijalankan dan sebagai modal bagi anggotanya tersebut untuk membangun kemampuan dalam meningkatkan pendapatannya. Walaupun pelaksanaan program UPPKS telah sesuai dengan prosedur yang ada namun belum sepenuhnya mampu meningkatkan kesejahteraan anggotanya. Hal ini tampak pada beberapa kelompok UPPKS, seperti pada kelompok UPPKS Melati I Pasar Usang yang mengaku belum mampu meningkatkan kesejahteraan anggota kelompoknya disebabkan jumlah bantuan modal yang diberikan kecil selain itu kurangnya 
kreatifitas dan inovasi dalam mencari dan memnfaatkan dana pinjaman yang ada juga membuat usaha yang dilakukan kelompok tidak berkembang.

2. Pelaksanaan program Usaha peningkatan pendapatan keluarga sejahtera di Kota Padang Panjang sudah terlaksana, namun belum optimal, seperti lemahnya pengawasan terhadap program, kurangnya modal yang diberikan pemerintah, dan pembinaan yang belum merata. Selanjutnya mekanisme pelaksanaan program UPPKS dimulai dari tahap persiapan sampai kepada pelaksanaan. Tahap persiapan dimulai dari pengelolaan kelompok dan pengelolaan administrasi dan keuangan serta pengelolaan usaha kelompok, setelah kelompok UPPKS melakukan tahap persiapan berlanjut keapada pelaksanaan yang dimulai dari pembentukan kelompok, pembuatan proposal usaha, membangun usaha kelompok, serta mengembangkan kelompok. Penyaluran dana program UPPKS diserahkan melalui koperasi AKU yang berkisar antara Rp. 2.500.000,- sampai Rp. 5.000.000,- untuk peminjaman pertama dengan bunga $0,6 \%$ perbulan, jangka watu peminjaman ini berkisar antara 1-2 tahun. Perkembangan program UPPKS yang ada di kota Padang Panjang dari bulan ke bulan mengalami peningkatan yang tercatat dari 25 kelompok yang ada sudah berkembang menjadi 32 kelompok UPPKS pada saat sekarang.

3. Kendala yang dihadapi dalam pelaksanaan program UPPKS di Kota Padang Panjang dapat dikategorikan kedalam dua bentuk yaitu kendala internal dan kendala eksternal. Kendala internal adalah (1)lemahnya pengawasan terhadap program. (2)kurangnya modal yang bersumber dari pemerintah. (3)pembinaan yang belum merata. Sedangkan kendala eksternal yaitu (1)pemanfaatan dana bantuan yang belum maksimal. (2)kurangnya kreatifitas dan inovasi beberapa kelompok dalam mencari dan memanfaatkan sumber dana. (3)keterlambatan pengembalian pinjaman.

4. Untuk mengatasi kendala dalam proses pelaksanaan program UPPKS antara lain mengikut sertakan keluarga sejahtera III bertindak sebagai bapak angkat dalam keompok, melakukan pembinaan, dan kendala yang bersumber dari peserta program dilakukan upaya seperti pembimbingan mengenai tujuan sebenarnya program UPPKS ini, melakukan sistem jemput bola terhadapa anggota yang macet dalam pembayaran.

\section{Saran}

Dari penelitian yang dilakukan peneliti dapat ditarik kesimpulan bahwa pemberdayaan masyarakat miskin melalui program usaha peningkatan pendapatan keluarga sejahtera di Kota Padang Panjang belum maksimal. Untuk memaksimalkan hal tersebut, peneliti menyarankan kepada pelaksana untuk memperbaiki pelaksanaan program dengan cara :

1. Meperkuat pengawasan yang dilakukan terhadap kelompok-kelompok UPPKS yang ada, sehingga pelaksanaan yang dilakukan dapat berjalan sebagaiman mestinya

2. Memberikan pengetahuan-pengetahuan tentang cara-cara pemanfaatan dan pencarian dana usaha yang lain secara baik dan benar.

3. Pemerataan pembinaan terhadap setiap kelompom UPPKS yang ada, supaya dapat mengembangkan usaha dan meningkatkan pengahsilannya.

4. Memberikan sanksi yang tegas terhadap kelompok yang melakukan pengembalian menunggak, hal ini bertujuan supaya dana tersebut betul-betul dimanfaatkan untuk pengembangan usaha. 


\section{DAFTAR PUSTAKA}

Abdul Wahab, Solichin. 2001. Analisis Kebijakan dari Formulasi ke Implementasi Kebijakan Negara. Edisi kedua. Jakarta: Bumi Aksara.

Badan Pusat Statistik. 2009. Penduduk Miskin (PoorPopulation). Berita Resmi Statistis Penduduk Miskin No.04/Th.II/July. Jakarta : CBS.

Badan Pusat Statistik Kota Padang Panjang. 2012. Padang Panjang dalam angka 2011/2012. Padang Panjang : BPS Kota Padang Panjang.

BKKBN. 2005. "Kelompok UPPKS sebagai Model Pemberdayaan Ekonomi Keluarga". Jakarta: BKKBN.

BKKBN. 2011. "Pedoman Pengelolaan dan Pengembangan Kelompok UPPKS". Padang : BKKBN

Budi Winarno. 2002. Kebijakan Dan Proses Kebijakan Publik. Yogyakarta : Media Persindo.

Burhan Bungin. 2003. Analisis Data Penelitian Kualitatif, Pemahaman Filosofi dan Metode Logis Kearah Pembangunan Model Aplikasi. Jakarta : Rajawali

Edi Suharto. 2005. Membangun Masyarakat Memberdayakan Masyarakat. Bandung : PT Refika Aditama.

Ginanjar Kartasmita. 1995. Pemberdayaan Masyarakat : sebuah tinjauan administrasi. Malang : Unibraw Press.

Kantor Pemberdayaan Perempuan dan Keluarga Berencana Kota Padang Panjang. 2009. Profil UPPKS kota Padang Panjang. Padang Panjang : Kantor Pemberdayaan Perempuan dan Keluarga Berencana Kota Padang Panjang.

Lexy J Muleong. 2002. Metodologi Penelitian Kualitatif. Bandung : PT Remaja Rosdakarya.

2005. Metodologi Penelitian Kualitatif Edisi Refisi. Bandung : PT Remaja Rosdakarya.

Mulia, R. A., \& Saputra, N. (2019). Kontribusi Kompensasi Dan Motivasi Kerja Terhadap Kepuasan Kerja Pegawai Di Dinas Pendidikan Dan Kebudayaan Kabupaten Agam.

Mulia, R. A. (2019). PERANAN PROGRAM KOPERASI JASA KEUANGAN SYARIAH BAITUL MAAL WAT TAMWIL (KJKS BMT) DALAM PEMBERDAYAAN PELAKU USAHA MIKRO KECIL MENENGAH DI KOTA PADANG.

Mulia, R. A. (2019). INFLUENCE OF PUBLIC POLICY, PARTICIPATION OF COMMUNITY AND EDUCATION LEVEL TO PUBLIC WELFARE IN PADANG PARIAMAN DISTRICT. Jurnal EL-RIYASAH, 10(1), 37-56.

Ony S Prijono dkk. 1996. Pemberdayaan : Konsep, Kebijakan, dan Implementasi. Jakarta : Center for Strategic and International Studies.

Roesmidi dan Risyanti. 2006. Pemberdayaan Masyarakat. Sumedang : Alqaprint Jatinangor.

Soerjono Soekanto. 2010. Sosiologi Suatu Pengatar. Jakarta: PT Raja Grafindo persada.

Sugiarti. 2003. Pembangunan Dalam Perspektif Gender. Malang : UMM.

Sugiyono. 2008. Penelitian Kuantitatif dan Kualitatif. Bandung : Alfabeta.

Wibowo. 2007. Manajemen Kinerja. Jakarta : PT Raja Grafindo Persada. 